\title{
Bosna-Hersek’te Türkçe Öğretiminin Güncel Durumu
}

Mehmet Emre Çelik*

Makale Geliş Tarihi: 28/12/2020

Makale Kabul Tarihi: 27/01/2021

DOI: $10.35675 /$ befdergi. 848525

$\ddot{O} z$

21. yüzyllın başlarından itibaren dünyada Türkçe ögretimi faaliyetleri hız kazanmıştır. Özellikle Balkanlarda yaşayan halkların Türkçe öğrenmeye yönelik motivasyonları yüksektir. Bu çalışmada, günümüzde Bosna Hersek'te Türkçe ögretimini yürüten kurumlar ve bunların etkinlikleri, üniversiteler bünyesindeki Türkoloji bölümlerinin tanttllp incelenmesi ile Türkçenin orta ve uzun vadedeki geleceğinin tartışılması amaçlanmıştır. Çalışmanın, Bosna Hersek'te Türkçenin güncel durumu hakkinda genel bir perspektif sunacağl; araştırma yapacak konunun uzmanlarına ayrıntıl bilgiler vereceği düşünülmektedir. Bu bağlamda TIKA, Saraybosna Yunus Emre Enstitüsü, Mostar Yunus Emre Enstitüsü, Fojnica Yunus Emre Enstitüsü, Maarif Koleji ile Saraybosna, Zenica, Tuzla, Mostar Džemal Bijedić ve Uluslararası Saraybosna Üniversitelerinin Türkoloji bölümleri incelenmiştir. Çalışmanın yöntemi betimsel tarama modelidir. Çalışmanın sonuç bölümünde Bosna Hersek'te Türkçe ögretiminde görülen eksikliklere yer verilmiştir. Ayrıca Türkçenin yaygınlaşması ve kalıcılı̆̆ını arttırmaya yönelik önerilere değinilmiştir.

Anahtar Kelimeler: Bosna Hersek, tercihim Türkçe projesi, Türkoloji, yabancılara Türkçe öğretimi, Yunus Emre enstitüsü

\section{Current Status of Turkish Teaching in Bosnia-Herzegovina}

\section{Abstract}

In this study, it has been purposed the followings; institutions carrying out teaching Turkish in Bosna Herzegovina today and their effectiveness, introducing and examining the Turcology departments in universities and discussing the medium-and long-term future of Turkish. It has been thought that this study will present a general perspective of the current status of Turkish in Bosnia Herzegovina and it will give detailed information to the experts who is to make a study. In this context, Turcology Departments of Yunus Emre Institution of Sarajevo, Yunus Emre Institution of Mostar, Yunus Emre Institution of Fojnica, Maarif Schools of Sarejevo, Zenica, Tuzla, Mostar Džemal Bijedić and International University of Sarajevo have been examined. The model of the study is descriptive research design. In conclusion part of the study, deficiencies observed in teaching Turkish in Bosnia Herzegovina have been handled. Also, proposals regarding popularizing Turkish and increasing its permanency have been referred.

Key Words: Bosnia Herzegovina, institution of Yunus Emre, teaching Turkish to foreginers, Turcology, Turkish elective courses

\footnotetext{
* Ondokuz Mayıs Üniversitesi, Samsun, Türkiye, mehmetemre.celik@omu.edu.tr, ORCID: 0000-00022961-0035 iD
}

Kaynak Gösterme: Çelik, M. E. (2021). Bosna-Hersek’te Türkçe öğretiminin güncel durumu. Bayburt Ĕ̈itim Fakültesi Dergisi, 16(Özel Sayı), 108-128. https://doi.org/10.35675/befdergi.848525 


\section{Giriş}

21. yüzyılın başlarından itibaren dünyada Türkçe öğretimi faaliyetleri hız kazanmıştır. Türkiye'nin dünya genelinde Türk dilini ve kültürünü tanıtmak üzere gerçekleştirdiği faaliyetler, çeşitli ülkelerdeki öğrencilerin yükseköğrenimlerini Türkiye'de tamamlama istekleri, Türk dizilerine olan ilginin artması, düzenlidüzensiz sığınmacı hareketliliğinde Türkiye'nin jeopolitik konumu, geçici koruma altındaki milyonlarca Suriyelinin Türkiye'deki varlığı bu durumun nedenleri arasında gösterilebilir. Özellikle Ortadoğu, Kafkaslar, Balkanlar, Türkistan coğrafyası, Doğu Avrupa, Afrika kıtasının geneli ile Orta ve Güney Amerika'da Türkçe öğrenmeye yönelik büyük bir talep olduğu görülmektedir. Bu talebin karşılanması için başta Yunus Emre Enstitüsü olmak üzere çeşitli üniversitelerin Türkoloji bölümleri, Türkçe öğretim merkezleri, Maarif Kolejleri ve özel kurslar hem Türkiye'de hem de Türkiye dışında öğretim etkinliklerini yürütmektedirler.

Bulgaristan, Batı Trakya, Makedonya ve Kosova'nın genelinde ana dilleri Türkiye Türkçesi olan milyonlarca soydaş yaşamaktadır (Özdemir, 2013; Kelağa Ahmet, 2014; Kayadibi, 2017; Çelik 2020). Dolayısıyla özellikle Balkanlarda, Türkçe bir taraftan ana dili olarak varlığını sürdürmekteyken öte taraftan tarihî, kültürel, sosyal ve siyasi ilişkiler açısından insanların öğrenmek için öncelik tanıdıkları dillerin başında gelmektedir.

Balkan ülkeleri arasında Türkçenin yabancı dil olarak en yoğun öğrenildiği ülke Bosna Hersek'tir. Bosna, ülkenin kuzeyinde; Hersek ise güneyinde kalan bölgenin adıdır. Ülkenin doğusunda Sırbistan; kuzey, batı ve güneyinde Hırvatistan; güneydoğusunda ise Karadağ bulunmaktadır. Bosna Hersek'in başkenti Saraybosna'dır. Tarihsel süreç içerisinde Hersek'te Mostar'ın sancak merkezi (18331851) olduğunu vurgulamak gerekir. 2018 sayımına göre ülkenin nüfusu yaklaşık 3,5 milyondur. Bosna Hersek'in yönetim yapısı ise oldukça karmaşıktır. Bosna Hersek Federasyonu, 1992-1995 yılları arasından yaşanan iç savaşın ardından imzalanan Dayton Anlaşması ile kurulmuştur. Bu anlaşmaya göre ülkede BosnaHersek Federasyonu ile Sırp Cumhuriyeti'nin yanı sıra Brćko Özerk Bölgesi'nin de varlığı kabul edilmiştir. Bosna Hersek Federasyonu'nun 10 kantonu (eyalet) bulunmaktadır. Ülkenin etnik yapısı Boşnak, Sırp ve Hırvatlardan oluşmaktadır. Ülkede seçimler dört yılda bir yapılmakta ve her etnik grup kendi cumhurbaşkanını seçmektedir. Seçilen cumhurbaşkanları bu görevi dönüşümlü olarak yürütmekte, dört yıl boyunca, 8 ayda bir kendi aralarında cumhurbaşkanlığını değiştirmektedirler. Dolayısıyla her bir cumhurbaşkanı, toplamda 16 ay bu makamda kalabilmektedir. Karar alınabilmesi için oy birliği şarttır. Ancak ülkede cumhurbaşkanlığı makamının da üstünde, dayanağını Dayton Anlaşması'ndan alan Bosna Hersek Yüksek Temsilciliği bulunmaktadır. Bu temsilciyi Avrupa Birliği atamaktadır. Öyle ki bu temsilcilik gerek gördüğü takdirde cumhurbaşkanını dahi görevden alma yetkisine sahiptir. Ülkedeki bu karmaşık idari yapı, devlet işlerinin olağan akışında yürütülmesinin önünde engel teşkil etmektedir. 


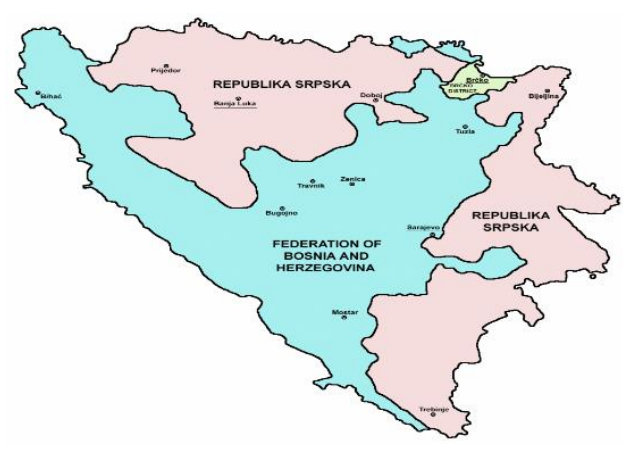

Şekil 1. Bosna Hersek Federasyonu haritası

Osmanlı Devleti Bosna'yı 1463'te, Hersek'i ise 1482'de fethetmiştir. Ancak Bosna Herseklilerin Türkler ile karşılaşmaları bu tarihlerden daha eskiye dayanmaktadır. Mostar'a bağlı Blagay'da bulunan 13. yüzyıla ait Sarı Saltuk Tekkesi bu bölgeye akıncıların çok önceden geldiğinin bir delili niteliğindedir. Osmanlı'nın fethinden önce Balkanlara gelen Hoca Ahmed Yesevi'nin talebeleri Alperenler ve Gazi-Dervişler örnek yaşantıları ile İslam'ın bölgede tanınıp, benimsenmesine öncülük etmişlerdir (Köprülü, 1988). O dönem bu coğrafyada var olan Bogomilizm inancı da taşıdığı özellikler itibarıyla tasavvufun yayılışını hızlandıran önemli etmenlerden olmuştur (Koltaş, 2014, s. 264). Osmanlı'nın fethettiği coğrafyalarda uyguladığı hoşgörü politikası sayesinde Bogomil Boşnaklar da İslamiyet'i kendi rızaları ile zaman içinde tercih etmişlerdir. Durum böyle olunca ortaya çıkan din adamı ihtiyacının karşılanabilmesi için İstanbul'a pek çok Boşnak öğrenci gönderilmiştir. $\mathrm{Bu}$ öğrenciler aldıkları eğitimde Türkçeyi de öğrendiklerinden Bosna Hersek’te dinî terminoloji çoğunlukla Türkçe şekillenmiştir. Devlet kademelerinde görev almaya başlayan Boşnakların sayısının artması Türkçenin sokağa inmesini ve günlük dilde sık karşılaşılan bir dil olmasını sağladı. Böylelikle Türkçe ile Boşnakça arasındaki alıveriş de hızlandı (Kırbaç, 2013, s. 902). Bu alışverişten Türkizm (Turcizm) kavramı doğdu. Türkizm, Türkçe kökenli olmayıp Türkçe aracılığıyla Boşnakçaya geçen sözcükler için kullanılmaktadır. Faruk İbrahimović (2012) Türkçeden Boşnakçaya geçen sözcükleri derlediği sözlüğünde 8400 sözcüğe yer vermiştir. Günümüzde bu sözcüklerden pek azı gündelik hayatta kullanılmaktadır. Bu kelimelerden bazıları şunlardır: Boja (boya), čekić (çekiç), ćumur (kömür), čarapa (çorap), česma (çeşme), čardak (çardak), čaršija (çarşı), ćefin (kefen), čelik (çelik), čizma (çizme), čorba (çorba), ćilim (kilim), dugme (düğme), kahva (kahve), kaiš (kayış), kajmak (kaymak), kapija (kapi), kašika (kaşık), kafana (kahvehane), kesten (kestane), komšija (komşu), kreč (kireç), kula (kule), kutija (kutu), oglagija (oklava), pamuk (pamuk), peškir (peşkir), pekmez (pekmez), rakija (rakı), sanduk (sandık), sarma (sarma), šećer (şeker), sirće (sirke), ugursuz (uğursuz), jastuk (yastık), jorgan (yorgan), jufka (yufka) vd.

Osmanlı'nın bölgeye gelmesiyle Boşnaklar hem Osmanlı eğitim kurumları hem de Türkçeyle resmî olarak karşılaşmışlardır. Bu eğitim kurumlarından "en meşhur olanları Saraybosna'daki Gazi Hüsrev Bey, Tuzla'daki Behram Bey ve Travnik’te Elçi İbrahim Paşa medreseleridir. Medreselerde dersler Türkçe verilmiştir. Gazi Hüsrev Bey, 1537 yılında medresenin yanına bir de kütüphane kurmuştur. Kütüphanede Türkçe, Arapça ve Farsça yüzlerce el yazması eser saklanmaktadır" 
(Začinović, 2003, s. 12). Mostar'daki Karagöz Bey Medresesi de Hersek bölgesindeki önemli eğitim kurumlarından biridir. Sırp Cumhuriyeti'nin başkenti olan Banja Luka şehrinde Gazanferi Camii'nde bulunan Mehmed Zahirovic Kütüphanesi'nde, Osmanlı döneminden kalma 720 el yazması eser bulunmaktadır (Anadolu Ajansı, 2020). Osmanlı'nın açtığı sıbyan mektepleri ve medreseler sayesinde Türkçe yaygınlaşmış, zamanla edebiyat dili olarak da kendini göstermiştir. Ana dili Boşnakça olan bazı müelliflerin 17, 18 ve 19. yüzyılda önemli Türkçe eserlere imza attı̆g görülmektedir. Bunların başlıcaları Rûz-nâme'nin yazarı Molla Mustafa Başeski ve Târih-i Bosna'nın yazarı Saraybosnalı Salih Sıdkî'dir (Začinović, 2003, s. 12-13). Ziyâî mahlasını kullanan 16. yüzyıl şairlerinden Mostarlı Hasan Ziyâî ve Hüsam Çelebi (Adlî) de çok sayıda Türkçe gazel sahibidir (TDV, 2005, s. 300).

19. yüzyılın ikinci yarısında Bosna Hersek'te Türkçenin oldukça yaygın konuşulduğunu söylemek mümkündür. Çünkü bu dönemde başlayan gazetecilik faaliyetlerinde kullanılan diller arasında Türkçe de yerini almıştır. İlk gazete Bosanski Vjestnik Kiril alfabesi kullanılarak Boşnakça çıkarılmıştır. Ardından Osmanlı hâkimiyetinin olduğu dönemde hem Kril hem de Türk harfleriyle haftalık Bosna (1866-1878), Gülşen-i Saray (1868-1872) ve Neretva (1876); AvusturyaMacaristan İmparatorluğu'nun egemenliğindeki (1878-1918) Bosna Hersek'te ise sadece Türk harfleriyle haftalık basılan Vatan (1884-1897) ve Rehber (1897-1902), on beş günde bir Arap, Latin ve Türk harfleriyle basilan Behar (1900-1911), aylık olarak Arap, Latin ve Türk harfleriyle basılan Muallim (1910-1913) ve Tarik (19081910) gazeteleri yayımlanmıştır (Začinović, 2003, s. 18-21).

1878'de imzalanan Berlin Anlaşması ile Bosna Hersek, Avusturya Macaristan İmparatorluğu'nun egemenliğine girmiştir. $\mathrm{Bu}$ süreçte de okullarda Türkçe öğretimine devam edilmiştir. Öğrencilerin girdikleri sınavlarda Türkçeden de sorumlu tutuluyor oluşu Vatan gazetesinin haberlerine yansımıştır. Gazetenin 1885 tarih ve 39 numaralı sayısında çıkan "Rüştiye İmtihanı" başlıklı yazısında Saraybosna'daki rüştiyeye devam eden seksenden fazla öğrencinin girdiği sınavda fen bilimlerinden sorular olmasının yanında Arapça, Farsça, Türkçe ve Boşnakça dillerinden de sorular bulunduğu ifade edilmektedir. Rüştiyelerde öğrencilere, birinci sinıftan sekizinci sınıfa kadar toplam 50 saat Arapça, Farsça ve Türkçe dersleri okutulmaktadır. Bu dersler arasında; sarf (şekil bilgisi/morfoloji), nahiv (cümle bilgisi/sentaks), kıraat temrinâtı (okuma alıştırması), edebiyat, kitâbet (yazma), kavaid-i Farisiye (Farsça dil bilgisi), hat ve imlâ gibi dersler bulunuyordu. (Geçer, 2010, s. 387). Her ne kadar gazeteler de basılsa, dersler de okutulsa Avusturya Macaristan İmparatorluğu döneminde Türkçe, Bosna Hersek’te gerilemeye başlamıştır. Boşnakça yazımda üç farklı alfabenin (Osmanlı Türkçesi, Latin ve Kiril harfleri) ortaya çıkması Türkçenin kullanım alanını giderek daraltmıştır (Geçer, 2009, s. 12).

Avusturya-Macaristan İmparatorluğu'nun ardından Bosna Hersek, 1918'de "Yugoslavya Krallığı" topraklarına katılmıştır. 1943 yılında "Demokratik Federal Yugoslavya" ilan edilmiş, 1946 yılında bu devletin adı "Yugoslavya Sosyalist Federal Cumhuriyeti” olmuştur. 1945-1980 yılları arasında Devlet Başkanlığını yürüten Tito'nun ölümünün ardından Yugoslavya parçalanma sürecine girmiş; Slovenya, Makedonya, Hirvatistan sirayla bağımsılıklarını ilan ederek Yugoslavya'dan ayrılmıştır. Bosna Hersek de bir referandum sonucunda 1992'de 
bağımsızlığını ilan etmiştir. Sırplar ve Hırvatlar, Bosna Hersek topraklarını kendi aralarında paylaşmak istemiş; bu istek, ülkedeki etnik gruplar arasında bir iç savaş başlamasına neden olmuştur. 1995 yılında imzalanan Dayton Anlaşması ile günümüzdeki Bosna Hersek siyasi ve idari yapısı ortaya çıkmıştır.

Bu çalışmada, günümüzde Bosna Hersek’te Türkçe öğretimini yürüten kurumlar ve bunların etkinlikleri, üniversitelerin bünyesindeki Türkoloji bölümlerinin tanıtılıp incelenmesi ile Türkçenin orta ve uzun vadedeki geleceğinin tartışılması amaçlanmıştır. Çalışmanın, Bosna Hersek’te Türkçenin güncel durumu hakkında genel bir perspektif sunacağı; araştırma yapacak konunun uzmanlarına ayrıntılı bilgiler vereceği düşünülmektedir. Bu bağlamda, çalışmada şu problem durumlarına yanıt aranmıştır:

1- Bosna Hersek’te Türkçe öğretimi faaliyetleri yürüten ve yürütülmesine katkısı olan Türkiye Cumhuriyeti'ne ait kurum ve kuruluşlar (TİKA, Saraybosna Yunus Emre Enstitüsü Kültür Merkezi, Mostar Yunus Emre Enstitüsü Kültür Merkezi, Fojnica Yunus Emre Enstitüsü Kültür Merkezi ve Maarif Koleji) ve bunların faaliyetleri nelerdir?

2- Bosna Hersek’te Türkçe öğretimi faaliyetleri yürüten ve yürütülmesine katkısı olan Bosna Hersek'e ait kurum ve kuruluşlar (Saraybosna, Zenica, Tuzla, Mostar Džemal Bijedić ve Uluslararası Saraybosna Üniversitelerinin Türkoloji bölümleri) ve bunların faaliyetleri nelerdir?

\section{Yöntem}

Çalışmada, nitel araştırma yöntemlerinden tarama yöntemi kullanılmıştır. "Tarama yöntemi; geçmiş̧te ya da hâlen var olan bir durumu var olduğu şekliyle betimlemeyi amaçlayan araştırma yaklaşımlarıdır. Araştırmaya konu olan olay, birey ya da nesne, kendi koşulları içinde olduğu gibi tanımlanmaya çalışılır. Onları, herhangi bir şekilde değiştirme, etkileme çabası gösterilmez" (Karasar, 2012, s.77). Araştırmanın çalışma grubunu, Bosna Hersek'te Türkçe öğretimini yürüten ve bunları destekleyen kurumlar oluşturmaktadır.

\section{Bulgular ve Yorum}

Bosna Hersek'te Türkçe öğretimi faaliyetleri yürüten ve yürütülmesine katkısı olan kurum ve kuruluşlara dair bulgu ve yorumlara yer verilmiş̧tir.

\section{Bosna Hersek’te Türkçe Öğretimi Faaliyetleri Yürüten ve Yürütülmesine Katkısı Olan Türkiye Cumhuriyeti'nin Kurum ve Kuruluşları}

\section{Türk İşbirliği ve Koordinasyon Ajansı Başkanlığı (TiKA)}

TİKA, 90'lı yılların başında SSCB'nin dağılmasının ardından Türkistan coğrafyasında bağımsızlığını elde eden Türk devletlerinin kendi sosyal yapılarını üretmesi, kendi kimliklerini sağlıklı bir şekilde inşa etmesi, kültürel ve siyasi haklarının geliştirilmesi, teknik alt yapı konusunda eksiklerinin giderilmesi amacıyla kurulmuştur. Günümüzde ise dost, kardeş ve akraba ülkelere yönelik eğitim, sağlık, restorasyon, tarımsal kalkınma, maliye, turizm, sanayi alanında birçok proje ve faaliyet TíKA tarafindan gerçekleştirilmektedir. "Türkiye'nin, TİKA aracılığı ile yürüttüğü çalışmaların temelinde bir barış kuşağı oluşturma çabası bulunmaktadır" (TİKA, 2020). 
Bosna Hersek'te iç savaşın hemen ardından 1995'te faaliyetlerine başlayan TİKA, 25 yılda 900'den fazla projeye imza atmıştır (Balkan Günlüğü, 2020). TİKA, din ve ırk ayrımı gözetmeksizin tarihî ve kültürel mirasın korunmasından eğitime, sağlıktan altyapıya, tarımdan hayvancılığa dek pek çok alanda Bosna Hersek'in yeniden ayağa kalkması için gayret göstermektedir.

TİKA’nın Bosna Hersek’te Türkçe öğretimine yönelik yürüttüğü çalışmaların başında 2001 'de Tuzla ve 2005 'te de Zenica şehirlerindeki üniversitelerde Türkoloji bölümlerinin açılmasını sağlamak, Türkçenin seçmeli ders olarak okutulduğu farklı şehirlerdeki okullara tadilat ve donanım desteği sunmak, bunların teknolojik altyapı ve üstyapı olanaklarını geliştirmek gelmektedir. Bu kapsamda yakın zamanda TIKKA eliyle tamamlanan projelerden bazıları şunlardır: Saraybosna'da Edhem Mulabdić İlköğretim Okulu'na Türkçe sınıfi açılması (TİKA, 2016), Bosanska Krupa'da Pištaline İlköğretim Okulu'nun yenilenmesi (Anadolu Ajansı, 2019a), Novi Travnik'te Safvet-beg Bašagić İlköğretim Okulu'nun inşaatı ve donanımının tamamlanması (Anadolu Ajansı, 2018), Kiseljak'ta Kiseljak İlköğretim Okulu'na donanım desteği sunulması (TİKA, 2017) vd.

TİKA’nın çalışmalarının yanı sıra Türk Silahlı Kuvvetleri'nin unsurları da Bosna Hersek’teki okulların altyapı ve üstyapılarının iyileştirilmesine katkı sunmaktadır. Bu çalışmaları, Türkiye'nin küresel barış çabaları kapsamında Avrupa Birliği Barış Gücü (EUFOR) bünyesinde Bosna Hersek'te görev yapan Türk Temsil Heyet Başkanlığı'na bağlı birimler yürütmektedir. Yürütülen tüm bu çalışmalar Bosna Hersek'te okullarda Türkçe dersinin seçimine yönelik farkındalığı arttırmakta, Türkçenin kalıcılığını güçlendirmektedir. İç savaşın ardından Bosna-Hersek’te Türkçe öğretimi faaliyetlerini ilk başlatan da Türk Silahlı Kuvvetleri'nin Saraybosna'daki birliği olmuştur. Düzenlenen kurslar ile Saraybosnalılara Türkçe öğretmek hedeflenmiş ve başarıya ulaşılmıştır.

\section{Yunus Emre Enstitüsü}

2007'de kurulan Yunus Emre Vakfi'na bağlı olarak 2009'da faaliyetlerine başlayan Yunus Emre Enstitüsü, yurt dışında kurduğu merkezlerde yabancılara Türkçe öğretimi çalışmalarının yanı sıra Türkiye'nin tanıtımı amaciyla kültür ve sanat faaliyetleri yürütmekte ayrıca bilimsel çalışmalara destek vermektedir (YEE, 2009). 46 ülkede toplam 58 merkezi bulunan Yunus Emre Enstitülerinin Bosna Hersek'te günümüzde üç merkezi bulunmaktadır. Sınırları içinde üç merkez bulunduran bir diğer ülke ise Kosova'dır.

Türkiye ile Bosna Hersek arasındaki tarihî, siyasi ve kültürel geçmiş dikkate alınarak Yunus Emre Enstitüsü kültür merkezlerinin ilkinin 17 Ekim 2009'da Saraybosna'da açılmış olması dost iki ülke arasındaki bağın önemini vurgulayan önemli bir mesaj olmuştur. İkinci merkez, Saraybosna'nın $60 \mathrm{~km}$. batısındaki Fojnica şehrinde 9 Ekim 2011 tarihinde hizmete girmiştir. Fojnica'nın hem Türkler hem de Bosna'daki Katolikler açısından sembolik bir önemi vardır. Fatih Sultan Mehmet'in Bosna'yı fethinden sonra ülkedeki Fransisken rahiplere özgürlük bahşettiği Ahitname, 557 yıldır Fojnica şehrindeki Fransisken Katolik Kilisesi'nde muhafaza edilmektedir. Bosna Hersek'teki üçüncü merkez, Hersek bölgesinin en önemli şehri olan Mostar'da 2014 yılında hizmete başlamıştır. 
Yunus Emre Enstitüsü kültür merkezlerinde Avrupa Dilleri Ortak Çerçeve Programı'na uygun olarak A1-A2, B1-B2, C1 ve C2 düzeylerinde kurslar düzenlenmektedir. Haftada altı saatlik periyodlarla devam eden kurlar 12 haftada $(\mathrm{A} 1.1+\mathrm{A} 1.2=144$ saatte $)$ tamamlanmaktadır. Derslerde Yunus Emre Enstitüsü tarafından hazırlanan Yedi İklim Türkçe Öğretim Setleri kullanılmaktadır. Merkezlerdeki okutmanlar Türkiye'den görevlendirilebildiği gibi yeterli donanıma sahip yerel halktan da seçilebilmektedir.

Bosna Hersek'teki merkezler arasında en fazla öğreniciyi kabul etme potansiyeline sahip olanı Saraybosna'dakidir. Bu merkezde bir yıl içinde 3 kurs dönemi başlangıcı yapılmaktadır. Kurlarının herhangi birinde sınıf açılabilmesi için en az 8 öğrenicinin başvuru yapması gerekmektedir. Saraybosna'daki merkez her dönem, tüm kurlarda sınıf açmakta ve merkezin öğrenici sayısı 250'nin üzerinde olmaktadir.

Yunus Emre Enstitülerinde sadece Türkçe öğretimi yapılmamakta aynı zamanda geleneksel Türk el sanatlarının tanıtılıp öğretilmesine yönelik kurslar düzenlenmektedir. Bunlar arasında; hüsn-i hat, çini işlemeciliği, ebru sanatı, ahşap baskı ön plana çıkmaktadır. Merkezde Osmanlı Türkçesi, Türk yemekleri ve ney kursu da verilmektedir. 2020 itibarıyla merkezde geleneksel Türk okçuluğu kursuna da başlanmıştır. Tüm bu kursların yanı sıra merkezde Türkçe Konuşma Kulübü açılmakta ve Bosna Herseklilerden yoğun ilgi görmektedir. Hem Türkçe kurslarına hem de adı geçen diğer kurslara katılanların toplam sayısı yıl içinde binin üzerindedir. Saraybosna'daki merkez açıldığından bu yana 6 bin civarında öğreniciye Türkçe sertifikası verilmiştir (Anadolu Ajansı, 2019b).

Yunus Emre Enstitüleri her iki ülkenin de özel ve önemli günlerinde öğrenicileri bir araya getirmektedir. "Türk kültür merkezleri, gerek Bosna-Hersek'e gerekse Türkiye'ye ait özel günlerde ve haftalarda sosyal etkinlikler düzenlemektedir. Cimburjada Bahar Şenliği, 23 Nisan Ulusal Egemenlik ve Çocuk Bayramı Senliği, Ahitname Töreni, Ayvaz Dede ve Musalla Şenlikleri bu etkinliklerdendir" (Ilgar \& Çangal, 2013, s. 281). Yunus Emre Enstitüsünün sadece Türk kültürüne değil; aynı zamanda hedef kitlenin kültürüne de değinmesi kültürlerarası iletişimsel yeterlik bakımından oldukça önemlidir. Kültürlerarası iletişimsel yeterliği esas alan dil öğretiminin temelinde hedef kültüre ait unsurların öğretimi esas alınırken aynı zamanda öğrenicinin kültürüne de değinerek öğrenciye ait kültürün değerli olduğuna vurgu yapılır. Bu durum dil öğrenicisinin hedef kültüre ait arka plan bilgisini artırarak hedef dili daha iyi öğrenmesini ve hedef dilin toplumuna daha kolay uyum sağlamasına yardımcı olur (İltar, 2020, s. 56).

Saraybosna'nın ardından en fazla öğrenici potansiyeline sahip olanı Mostar'daki merkezdir. Her bir dönemde (güz ve bahar) 60'tan fazla öğrenci Türkçe öğrenmek için kurslara kaydolmaktadır. 2014'ten bu yana yaklaşık 800 öğrenici kurslardan faydalanarak Türkçe öğrenmiştir (YEE, 2019). Mostar'da ayrıca Kayseri Büyükşehir Belediyesi'nin açtı̆̆ 1 Meslek Edindirme Merkezi (KAYMEK) bulunmaktadır. Bu merkezde çeşitli el sanatları kursları düzenlenerek Mostarlıların hizmetine sunulmaktadır.

2011 yılından itibaren Yunus Emre Enstitüsünün yürüttüğü "Tercihim Türkçe Projesi” ile Bosna Hersek ilk ve orta dereceli devlet okullarında Türkçe, seçmeli ikinci dil olarak okutulmaya başlanmıştır. Bu proje kapsamında 2018-2019 eğitim- 
öğretim yılında ülke genelinde 7 kantonda 150 okulda 8552 öğrenci haftada iki saat Türkçe dersini almaktadır (Çangal \& Göktaş, 2019, s. 275). Bu öğrencilerin 1541'i Hersek-Neretva Kantonu'nda bulunmakta ve Mostar Yunus Emre Enstitüsü'nün sorumluluk alanındadır. $\mathrm{Bu}$ öğrencilerin derslerine Bosna Hersekli Türkçe öğretmenleri girmektedir. Bu öğretmenler Bosna Hersek’teki beş farklı üniversitenin Türkoloji bölümlerinden mezun olmaktadırlar. Tercihim Türkçe Projesi sayesinde Bosna Hersek'teki ilk ve orta dereceli okullarla Türkiye'deki denkleri arasında yüzlerce kardeş okul protokolleri imzalanmış böylelikle iki ülkenin çocukları karşılıklı olarak birbirlerine gelip gitmekte, kültürleri tanımaktadırlar.

Tablo 1 .

2020-2021 Eğitim-Öğretim Yılında Tercihim Türkçe Projesi Kapsamında Türkçe Dersini Seçen Ögrencilerin Kanton ve Sınıf Düzeyine Göre Dağılımı

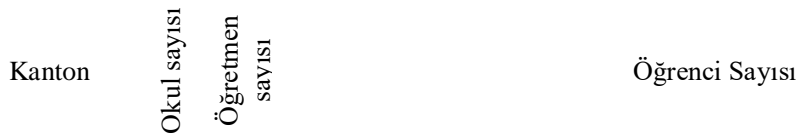

\begin{tabular}{|c|c|c|c|c|c|c|c|c|c|c|c|c|}
\hline & & & 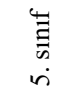 & $\begin{array}{l}\stackrel{\Xi}{\Xi} \\
0 \\
0\end{array}$ & 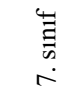 & $\begin{array}{l}\stackrel{4}{\Xi} \\
\infty \\
\infty\end{array}$ & $\begin{array}{l}\stackrel{4}{\Xi} \\
\dot{0}\end{array}$ & $\vec{D}$ & 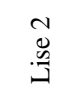 & 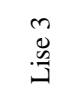 & 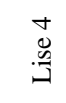 & $\frac{\Xi}{\frac{\Xi}{2}}$ \\
\hline $\begin{array}{l}\text { Zenica - } \\
\text { Doboy }\end{array}$ & 50 & 29 & - & 292 & 389 & 574 & 654 & 103 & 106 & 72 & 129 & 2319 \\
\hline $\begin{array}{l}\text { Orta } \\
\text { Bosna }\end{array}$ & 26 & 16 & - & 244 & 381 & 343 & 479 & 58 & 26 & 42 & 27 & 1600 \\
\hline $\begin{array}{l}\text { Saraybos } \\
\text { na }\end{array}$ & 23 & 15 & 118 & 143 & 141 & 121 & 196 & 56 & 59 & 43 & 48 & 925 \\
\hline $\begin{array}{l}\text { Bosna - } \\
\text { Podrinye }\end{array}$ & 4 & 2 & - & - & 25 & - & 16 & 8 & 27 & 25 & 53 & 154 \\
\hline Tuzla & 20 & 9 & - & 15 & 79 & 110 & 292 & - & - & - & - & 496 \\
\hline $\begin{array}{l}\text { Hersek - } \\
\text { Neretva }\end{array}$ & 27 & 20 & - & 109 & 224 & 177 & 208 & 110 & 126 & 127 & 174 & 1255 \\
\hline Una Sana & 6 & 1 & - & - & 4 & 26 & 124 & - & - & - & - & 154 \\
\hline Toplam & $\begin{array}{c}15 \\
6 \\
\end{array}$ & 92 & 118 & 803 & 1243 & 1351 & 1969 & 335 & 344 & 309 & 431 & 6903 \\
\hline
\end{tabular}

2020-2021 eğitim-öğretim yılında Tercihim Türkçe Projesi kapsamında BosnaHersek kantonlarının genelinde 156 okulda 6903 öğrenci Türkçe dersini seçmiş ve bu okullarda 92 Türkçe öğretmeni görev yapmaktadır. Bunlar, tamamı BosnaHersek’teki Türkoloji bölümlerinden mezun olmuş Bosna Hersekli öğretmenlerdir.

Tercihim Türkçe Projesi kapsamında Yunus Emre Enstitüsü ve Türk Dünyası Belediyeler Birliği'nin (TDBB) iş birliğiyle Bosna Hersek'te ilk ve orta dereceli pek çok okulda Türkçe sınıfları açılmış, bu okulların teknolojik donanımları ve fiziki şartları iyileştirilmiştir. Bu kapsamda yakın zamanda TDBB'nin desteğiyle tamamlanan projelerden bazıları şunlardır: Tešanj 9 Eylül İlköğretim Okulu'na Türkçe sınıfı açılması (YEE, 2018a), Srebrenik’te Rapatnica İlköğretim Okulu'nun yenilenmesi (TDBB, 2019a), Bužim'de Bužim İlköğretim Okulu'na Türkçe sınıfi açılması (YEE, 2018b), Jablanica'da Suljo Čilić İlköğretim Okulu'nda Türkçe sınıfının açılması (TDBB, 2019b) vd.

\section{Türkiye Maarif Vakfı Okulları}


Türkiye Maarif Vakfı (TMV), yurt dışında Türkiye Cumhuriyeti adına Millî Eğitim Bakanlığı dışında doğrudan eğitim kurumu açma yetkisine sahip tek kuruluştur. Kâr amacı gütmeyen, kamu yararına çalışan bir vakıf olan TMV, her ülkede okul öncesinden yükseköğretime eğitimin her aşamasında etkin faaliyet yürütmek amaciyla 2016'da kurulmuştur (TMV, 2016). Günümüzde 42 ülkede bulunan 339 eğitim kurumunda, 40.910 öğrenci TMV okullarında öğrenim görmektedir (TMV, 2020a).

TMV okulları Saraybosna'da 2018-2019 eğitim-öğretim yılından itibaren okul öncesi, ilköğretim ve ortaöğretim kademelerinde hizmete başlamıştır. Maarif okullarında Türkçe dersleri, ilgili ülkelerin resmî programlarına göre hazırlanan haftalık saatlerde zorunlu veya isteğe bağlı olarak okutulmaktadır. Türkçe dersleri uluslararası dil öğrenme standartlarına göre yürütülmektedir ve dersler Türkçenin pratik kullanımına yönelik ders dişı etkinlikler ve kulüp etkinlikleri ile desteklenmektedir. TMV, liseden mezun olabilecek öğrencilerin en az B2 düzeyinde Türkçe yeterliğe sahip olmalarını hedeflemektedir. Böylece, liseyi B2 düzeyinde Türkçe yeterlikle tamamlayan öğrenciler, bursun yanı sıra Türkiye'de yükseköğrenimlerine devam etme firsatı elde edebilmektedir. TMV, öğrencilerin Türkçe yeterlilik düzeyini ölçebilmek için Avrupa Dil Portföyünü (ELP) referans alır ve ELP yeterliliklerini ölçen merkezi bir Türkçe sertifika sınavı oluşturur (TMV, 2020b).

2020-2021 eğitim-öğretim yılında TMV Saraybosna Okullarında 210 öğrenci eğitim görmektedir. Türkçe dersi 5- 8. sınıflar aralığında ikinci yabancı dil olarak okutulmakta; 9-12. sınıflar aralığında ise dönem başında yapılan anketler neticesinde seçmeli olarak okutulmaktadır. TMV Saraybosna Okullarında tüm sınıf düzeylerinde öğrenciler Türkçe dersini almaktadır. Derslerde Yunus Emre Enstitüsü'nün hazırladığı "Haydi Türkçe Öğrenelim" serisi kullanılmaktadır. Tamamı Türkçe eserlerden oluşan bir kütüphanenin bulunmadığı okullarda biri Türkiye'den görevlendirilen ikisi de yerel halktan olmak üzere üç Türkçe öğretmeni görev yapmaktadır. TMV Saraybosna Okulları henüz yeni açılmasına rağmen Bosna Hersekliler tarafindan sahiplenilmiş; iki ülke arasındaki bağları kuvvetlendirmede Türkiye'nin önemli sembol kurumlarından olmuştur.

\section{Bosna Hersek’te Türkçe Öğretimi Faaliyetleri Yürüten ve Yürütülmesine Katkısı Bosna Hersek'e Ait Kurum ve Kuruluşlar}

\section{Saraybosna Üniversitesi}

Saraybosna Üniversitesi Türk Dili ve Edebiyatı Bölümü, 1950'de kurulan Felsefe Fakültesi Doğu Dilleri Kürsüsünde varlığını sürdürmektedir. Bölümün kurucusu Prof. Nedim Filipović'tir. Türkçenin yanı sıra kürsüde, Arapça ve Farsça bölümleri de açılmıştır. Müfredat tasarlanırken Arapça, Türkçe ve Farsça olarak yazılmış klasik ve çağdaş edebiyatı öğrenmeye hazırlanan akademisyenleri eğitecek özel bir program geliştirerek, Osmanlı dönemi kaynak materyallerini inceleyerek (Arapça, Türkçe ve Farsça zengin el yazması arşivi) Bosna Hersek halkının tarihini ve kültürünü araştırmak ayrıca akademik ve kültürel ihtiyacı karşılamak amaçlanmıştır.

Tablo 2.

Saraybosna Üniversitesi Türk Dili ve Edebiyatı Bölümü Ders Kataloğu 


\begin{tabular}{|c|c|c|}
\hline Lisans & Dersler & Dersler (Türkçe çevirileri) \\
\hline \multirow{5}{*}{ 1. dönem } & Bosanski, hrvatski, srpski jezik I & Boşnakça, Hırvatça, Sırpça I \\
\hline & Uvod u studij turkologije I & Türkoloji Çalışmalarına Giriş I \\
\hline & Uvod u lingvistiku & Dilbilime Giriș \\
\hline & $\begin{array}{l}\text { Fonologija i morfologija turskog } \\
\text { jezika }\end{array}$ & Türk Dilinin Fonoloji ve Morfolojisi \\
\hline & Metodika nastave I & Öğretme Metodolojisi I \\
\hline \multirow{5}{*}{ II. dönem } & Bosanski, hrvetski srpski iezik II & Boşnakça, Hırvatça, Sırpça II \\
\hline & Morfologija turskog jezika & Türk Dilinin Morfolojisi \\
\hline & Teorija i metodologija & Edebiyat Çalışmalarının Teori ve \\
\hline & proučavanja književnosti & Metodolojisi \\
\hline & Uvod u studij turkologije II & Türkoloji Çalışmalarına Giriş II \\
\hline \multirow{4}{*}{ III. dönem } & Morfologija turskog jezika & Türk Dilinin Morfolojisi \\
\hline & Moderna turska književnost I & Çağdaş Türk Edebiyatı I \\
\hline & Uvod u tursku književnost I & Türk Edebiyatına Giriş I \\
\hline & Uvod u orijentalnu filoligiju & Doğu Filolojisine Giriş \\
\hline \multirow{3}{*}{ IV. dönem } & Uvod u sintaksu turskog jezika & Türkçe Sözdizimine Giriş \\
\hline & Uvod u tursku književnost II & Türk Edebiyatına Giriş II \\
\hline & Metodika nastave II & Öğretme Metodolojisi II \\
\hline \multirow{4}{*}{ V. dönem } & Sintaksa turskog jezika I & Türk Dilinin Söz Dizimi I \\
\hline & Pragmatika turskog jezika I & Edimbilim I \\
\hline & Uvod $\mathrm{u}$ metodika nastave & Öğretme \\
\hline & turskog jezika I & Metodolojisine Giriş I \\
\hline \multirow{5}{*}{ VI. dönem } & Sintaksa turskog jezika II & Türk Dilinin Söz Dizimi II \\
\hline & Moderna turska književnost II & Çağdaş Türk Edebiyat II \\
\hline & Pragmatika turskog jezika II & Edimbilim II \\
\hline & Uvod $\mathrm{u}$ metodika nastave & Türk Dilini Öğretme \\
\hline & turskog jezika II & Metodolojisine Giriș II \\
\hline
\end{tabular}

Yüksek

lisans Uvod u osmanski jezik

Uvod u klasičnu osmansku književnost

Osmanski jezik

II. dönem

Klasična osmanska književnost

Pragmatika turskog jezika

Tvorba riječi u turskom jezika I Islamska paleografija

III. dönem

Postklasična osmanska književnost

Mastar Formların Söz Dizimi Osmanlı Türkçesine Giriş

Metodologija i tehnika naučnog rada

Klasik Osmanlı Edebiyatına

Giriş

Osmanlı Türkçesi

Klasik Osmanlı Dönemi

Edebiyatı

Edimbilim

Türkçede Sözcük Oluşturma I İslami Paleografya

Klasik Dönem Sonrası Osmanlı Edebiyat1

Bilimsel Çalışmanın

Metodolojisi ve Tekniği

Tvorba riječi u turskom jezika II Türkçede Sözcük Oluşturma II

Osmanski diplomatika

Osmanlı Dönemi Diplomasisi

IV. dönem

Divanska književnost na

Bosna Hersek'teki Divan osmanskom turskom jeziku u Edebiyatında Osmanlı Türkçesi 
$\mathrm{BiH}$

Leksikologija

Sözcükbilim

Saraybosna Üniversitesi Türk Dili ve Edebiyatı Bölümü’nde 240 ECTS'yi tamamlayan öğrenciler $5(3+2)$ yılda mezun olmaktadır. Bu beş yılın son iki yılı yüksek lisans olarak değerlendirilmektedir. Bölümde, biri Türkiye'den görevlendirilmiş toplam altı öğretim elemanı görev yapmaktadır. Bölümün, biri TİKA tarafindan teknolojik donanımı sağlanmış dört dersliği ve kendine ait bir kütüphanesi bulunmaktadır. 2020-2021 eğitim-öğretim yılında 1. sinıfta 35, 2. sinıfta 25, 3. sinıfta 20; 4. sinıfta 15, 5. sinıfta da 12 öğrenci bu bölümde eğitime devam etmektedir.

Saraybosna Üniversitesi Türk Dili ve Edebiyatı Bölümü, Balkanlarda ilk açılan Türkoloji bölümlerindendir. Bu zamana kadar pek çok mezun vermiş ve önemli akademik çalışmalar üretilmesini sağlamıştır. Sahip olduğu doktora programı ile Bosna Hersek’teki diğer Türkoloji bölümlerine de akademisyen yetiştirdiği için aynı zamanda bir merkezdir.

\section{Zenica Üniversitesi}

Zenica Üniversitesi Türk Dili ve Edebiyatı Bölümü, TİKA'nın da katkılarıyla 2005 'te Felsefe Fakültesi bünyesinde kurulmuştur. Yüksek lisans programı da bulunan bölümde lisans eğitim süresi 4 yıldır. Tamamı Türkçe eserlerden oluşan bir kütüphaneye sahip bölümde ikisi Türkiye'den görevlendirilmiş toplam dört öğretim üyesi bulunmaktadır. 2020-2021 eğitim-öğretim yılında 1. sınıfta 15, 2. sinıfta 15, 3 . sinıfta 20 ve 4 . sinıfta 15 öğrenci eğitimlerine devam etmektedir. Bölümün yüksek lisans programına devam öğrenci sayısı 15'tir.

Tablo 3.

Zenica Üniversitesi Türk Dili ve Edebiyatı Bölümü Ders Kataloğu

\begin{tabular}{cll}
\hline \multicolumn{1}{c}{ Lisans } & \multicolumn{1}{c}{ Dersler } & \multicolumn{1}{c}{ Dersler (Türkçe çevirileri) } \\
\hline \multirow{4}{*}{ 1. dönem } & Nastava turskog jezika I & Türkçe Öğretimi I \\
& Opća lingvistika & Genel Dilbilim \\
& Akademska pismenost & Akademik Okuryazarlık \\
& BHS jezik I & Boşnakça, Hırvatça, Sırpça I \\
& Uvod u književnost & Edebiyata Giriş \\
& Bosanski, hrvetski srpski iezik II & Boşnakça, Hırvatça, Sırpça II \\
II. dönem & Jezičke vježbe & Dil Alıştırmaları \\
& Turski jezik I & Türk Dili I \\
& Pedagogija & Pedagoji \\
& Nastava turskog jezika II & Türkçe Öğretimi II \\
& Fonetika turskog jezika & Türk Dilinin Ses Bilgisi \\
& Leksikologija & Sözcükbilim \\
& Kultura govora & Konuşma Kültürü \\
& Turski jezik II & Türk Dili II \\
& Psihologija odgoja i obrazovanja & Eğitim Psikolojisi \\
& Morfologija turskog jezika & Türk Dilinin Morfolojisi \\
& Divanska književnost & Divan Edebiyatı \\
IV. dönem & Turcizmi u bosanskom jeziku & Boşnakçada Türkizm \\
& Didaktika & Didaktik \\
& Turski jezik III & Türk Dili III \\
& Sintaksa turskog jezika & Türkçenin Sözdizimi \\
& Osmanski turski I & Osmanlı Türkçesi I \\
& & \\
& &
\end{tabular}




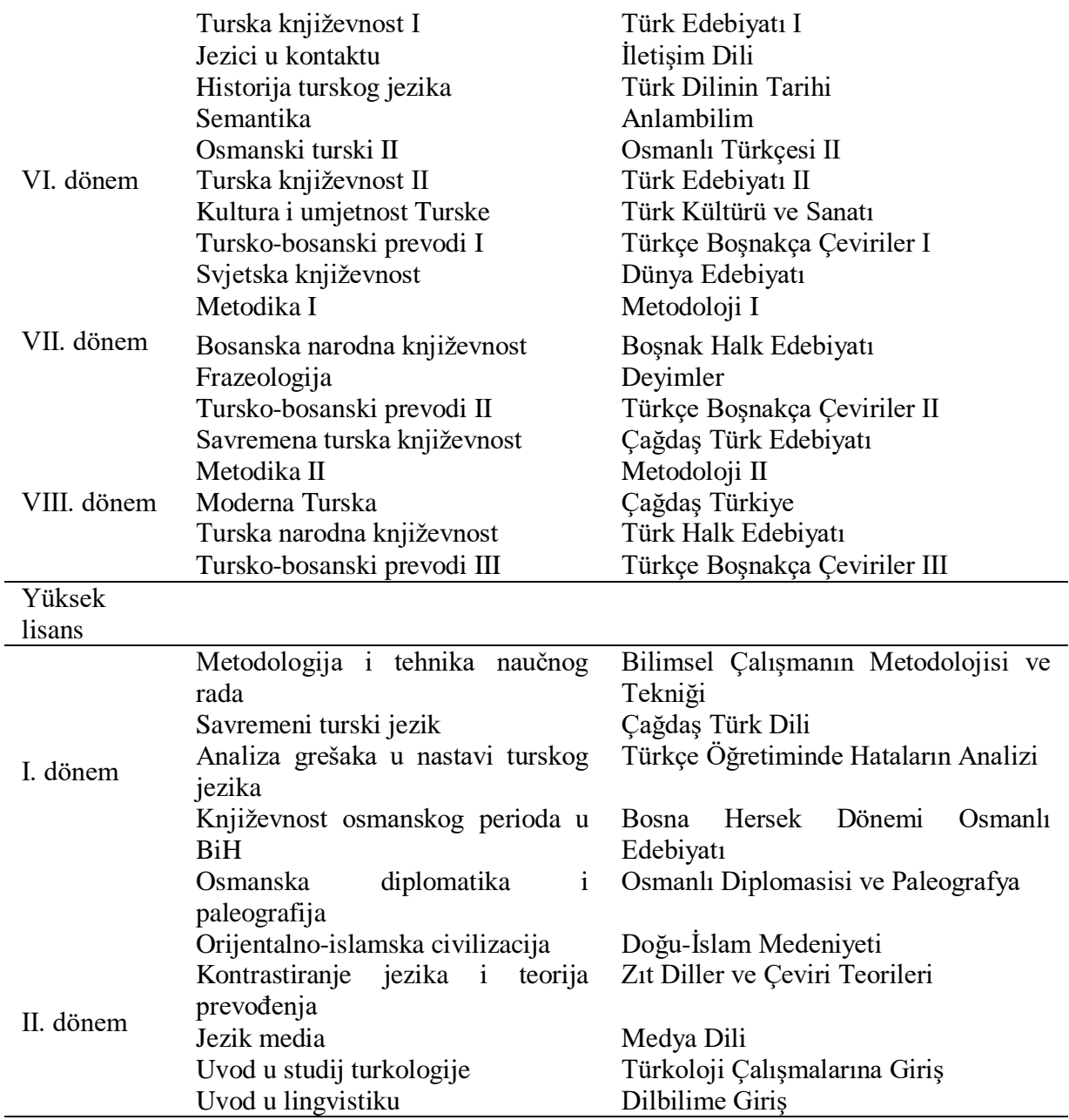

Zenica, Bosna Hersek'in kuzeyindeki büyük şehirlerdendir. Bu bölge ve çevresinde "Tercihim Türkçe Projesi" kapsamında ilk ve orta dereceli okullardaki pek çok öğrenci Türkçe dersini seçmektedir. Zenica Üniversitesi'ndeki Türk Dili ve Edebiyatı Bölümü'nün varlığı bu öğrenciler için de bir motivasyon kaynağı olmaktadır. Üniversiteye kadar eğitim hayatının bir döneminde Türkçe dersini seçmiş olan öğrenciler, üniversitede bu bölüme yoğun ilgi göstermektedirler.

\section{Tuzla Üniversitesi}

Tuzla Üniversitesi Türk Dili ve Edebiyatı Bölümü, TİKA'nın desteğiyle 2001'de Felsefe Fakültesi bünyesinde açılmıştır. Bölümde eğitim süresi 4 yıldır. Tamamı Türkçe eserlerden oluşan bir kütüphaneye sahip olan bölümde biri Türkiye'den görevlendirilmiş, toplam dört öğretim üyesi bulunmaktadır. 2020-2021 eğitimöğretim yılında 1. sinıfta 9, 2. sinıfta 10, 3. sinıfta 11 ve 4. sinıfta 16 öğrenci eğitimlerine devam etmektedir. 
Tablo 4.

Tuzla Üniversitesi Türk Dili ve Edebiyatı Bölümü Ders Kataloğu

\begin{tabular}{|c|c|c|}
\hline Lisans & Dersler & Dersler (Türkçe çevirileri) \\
\hline \multirow{5}{*}{ 1. dönem } & Savremeni turski jezik I & Çağdaş Türk Dili I \\
\hline & Turska historija I & Türkiye Tarihi I \\
\hline & Osnove gramatike i pravpisa $\mathrm{b} / \mathrm{h} / \mathrm{s} \mathrm{I}$ & $\begin{array}{l}\text { Boşnakça, Hırvatça, Sırpça Dil } \\
\text { Bilgisi ve Yazımın Temeli I }\end{array}$ \\
\hline & Uvod u turkologiju I & Türkolojiye Giriş I \\
\hline & Usmeno i pisano izražavanje I & Sözlü ve Yazılı Anlatım I \\
\hline \multirow{5}{*}{ II. dönem } & Savremeni turski jezik II & Çağdaş Türk Dili II \\
\hline & Turska historija II & Türkiye Tarihi II \\
\hline & Osnove gramatike i pravpisa b/h/s II & $\begin{array}{l}\text { Boşnakça, Hırvatça, Sirpça Dil } \\
\text { Bilgisi ve Yazımın Temeli II }\end{array}$ \\
\hline & Uvod u turkologiju II & Türkolojiye Giriş II \\
\hline & Usmeno i pisano izražavanje II & Sözlü ve Yazılı Anlatım II \\
\hline \multirow{5}{*}{ III. dönem } & Savremeni turski jezik III & Çağdaş Türk Dili III \\
\hline & Teorija književnost I & Edebiyat Teorisi I \\
\hline & Nova turska književnost I & Yeni Türk Edebiyatı I \\
\hline & Historija turskog jezika I & Türk Dili Tarihi I \\
\hline & Pedagogija sa didaktikom & Didaktik Pedagoji \\
\hline \multirow{5}{*}{ IV. dönem } & Savremeni turski jezik IV & Çağdaş Türk Dili IV \\
\hline & Teorija književnost II & Edebiyat Teorisi II \\
\hline & Nova turska književnost II & Yeni Türk Edebiyatı II \\
\hline & Historija turskog jezika II & Türk Dili Tarihi II \\
\hline & Psihologija & Psikoloji \\
\hline \multirow{5}{*}{ V. dönem } & Savremeni turski jezik V & Çağdaş Türk Dili V \\
\hline & Opća lingvistika & Genel Dilbilim \\
\hline & Osmanski turski jezik I & Osmanlı Türkçesi I \\
\hline & Nova turska književnost III & Yeni Türk Edebiyatı III \\
\hline & Prijevodi I & Çeviriler I \\
\hline \multirow{5}{*}{ VI. dönem } & Savremeni turski jezik VI & Çağdaş Türk Dili VI \\
\hline & Osmanski turski II & Osmanlı Türkçesi II \\
\hline & Nova turska književnost IV & Yeni Türk Edebiyatı IV \\
\hline & Prijevodi II & Çeviriler II \\
\hline & Tumačenje književnog teksta & Edebi Metin Yorumlama \\
\hline \multirow{6}{*}{ VII. dönem } & Savremena turska književnost I & Çağdaş Türk Edebiyatı I \\
\hline & Metodika I & Metodoloji I \\
\hline & Turska i bošjačka usmena & Türk ve Boşnak Sözlü Edebiyatı \\
\hline & književnost I & I \\
\hline & Osmanski turski III & Osmanlı Türkçesi III \\
\hline & Prijevodi III & Çeviriler III \\
\hline \multirow{6}{*}{ VIII. dönem } & Savremena turska književnost II & Çağdaş Türk Edebiyatı II \\
\hline & Metodika II & Metodoloji II \\
\hline & Turska i bošjačka usmena & Türk ve Boşnak Sözlü Edebiyatı \\
\hline & književnost II & II \\
\hline & Osmanski turski IV & Osmanlı Türkçesi IV \\
\hline & Prijevodi IV & Çeviriler IV \\
\hline
\end{tabular}


Tuzla, Bosna Hersek'in kuzeyinde ve sanayisi gelişmiş büyük şehirlerdendir. Türk firmalarının da bu bölgede çeşitli yatırımları bulunmaktadır. Dolayısıyla Tuzla Üniversitesi'ndeki Türk Dili ve Edebiyatı Bölümü'nden mezun olanlar öğretmenliğin yanı sıra bu sanayi bölgesindeki kuruluşlarda tercümanlık yapabilmektedirler.

\section{Mostar Džemal Bijedić Üniversitesi}

Mostar'da kurulu Džemal Bijedić Üniversitesi Türk Dili ve Edebiyatı Bölümü, TİKA'nın desteğiyle 2012'de Beşeri Bilimler Fakültesi bünyesinde açılmıştır. Yüksek lisans programı da bulunan bölümde lisans eğitim süresi 4 yıldır. Tamamı Türkçe eserlerden oluşan bir kütüphaneye sahip olan bölümde Türkiye'den görevlendirilmiş bir öğretim üyesi ve iki asistan bulunmaktadır. Bölümün kadrolu öğretim üyesi bulunmamaktadır. 2020-2021 eğitim-öğretim yılında 1. sınıfta 6, 2. sınıfta 11 ve 4 . sınıfta 6 öğrenci eğitimlerine devam etmektedir. Bölümün yüksek lisans programına devam öğrenci sayısı 12'dir. Bölümü tercih eden ögrrenciler arasında sadece Mostarlılar değil çevredeki küçük şehirlerden öğrenciler de vardır.

Tablo 5 .

Mostar Džemal Bijedić Üniversitesi Türk Dili ve Edebiyatı Bölümü Ders Kataloğu

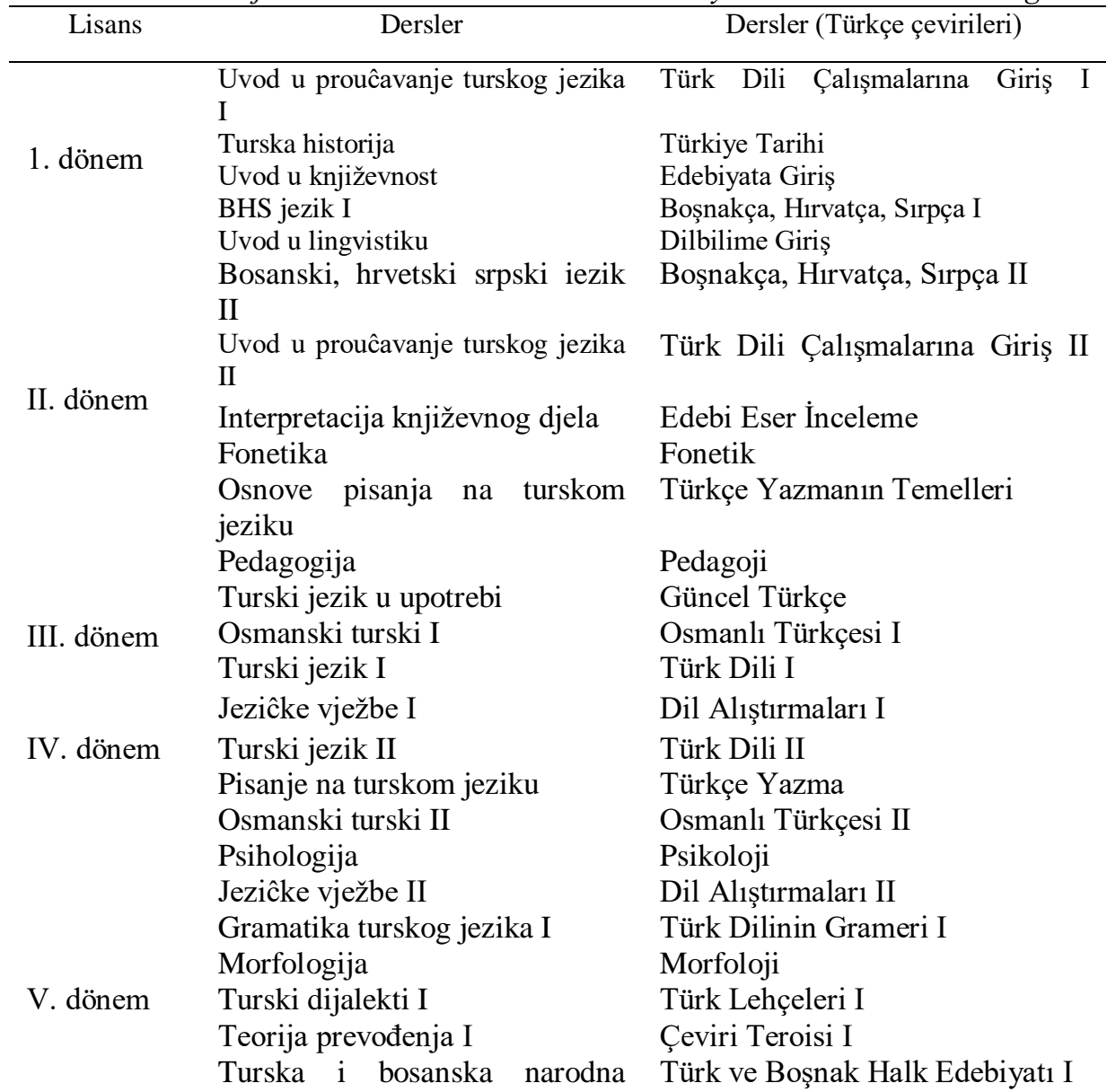




\begin{tabular}{|c|c|c|}
\hline \multirow{6}{*}{ VI. dönem } & njiţevnost I & \multirow[b]{2}{*}{ Türk Dilinin Grameri II } \\
\hline & Gramatika turskog jezika II & \\
\hline & Sintaksa & Cümle Bilgisi \\
\hline & Divanska književnost I & Divan Edebiyatı I \\
\hline & Teorija prevođenja II & Çeviri Teorisi II \\
\hline & $\begin{array}{l}\text { Turska i bosanska narodna } \\
\text { knjiţevnost II }\end{array}$ & Türk ve Boşnak Halk Edebiyatı II \\
\hline \multirow{6}{*}{ VII. dönem } & Semantika & Anlambilim \\
\hline & Nova turska književnost & Yeni Türk Edebiyatı \\
\hline & Tradicionalno tursko pozorište & Geleneksel Türk Tiyatrosu \\
\hline & ka nastave turskog jezika & Türk Dilin Öğretimi Metodolojisi \\
\hline & I & I \\
\hline & Divanska književnost II & Divan Edebiyatı II \\
\hline \multirow{6}{*}{ VIII. dönem } & ni turski jezik & Çağdaş Türk Dili \\
\hline & ena turska književnost & Çağdaş Türk Edebiyatı \\
\hline & $\begin{array}{l}\text { Metodika nastave turskog jezika } \\
\text { II }\end{array}$ & Türk Dilin Öğretimi Metodolojisi \\
\hline & Kultura i umjetnost osmanskog & Osmanlı İmparatorluğu'nun \\
\hline & carstva & Kültür ve Sanatı \\
\hline & $\begin{array}{l}\text { Uvod u tehnike izrade nauĉnog } \\
\text { rada }\end{array}$ & $\begin{array}{l}\text { Bilimsel Makale Hazırlama } \\
\text { Tekniklerine Giris }\end{array}$ \\
\hline \multicolumn{3}{|l|}{$\begin{array}{l}\text { Yüksek } \\
\text { lisans }\end{array}$} \\
\hline \multirow{5}{*}{ I. dönem } & a bib & Türk Dilinin Kaynakçası \\
\hline & $\begin{array}{l}\text { Interpretacija moderne turske } \\
\text { poezije i romana }\end{array}$ & $\begin{array}{l}\text { Modern Türk Şiir ve } \\
\text { Romanlarının Yorumu }\end{array}$ \\
\hline & $\begin{array}{l}\text { Pismena kultura izražavanja u } \\
\text { turskom jeziku }\end{array}$ & $\begin{array}{l}\text { Romanlarının Yorumu } \\
\text { Türkçe Yazılı Anlatım Kültürü }\end{array}$ \\
\hline & $\begin{array}{l}\text { Usmena kultura izražavanja u } \\
\text { turskom jeziku }\end{array}$ & Türkçe Sözlü Anlatım Kültürü \\
\hline & $\begin{array}{l}\text { Moderna turska književnost u } \\
\text { književnoj kritici }\end{array}$ & $\begin{array}{l}\text { Modern } \\
\text { Eleştiri }\end{array}$ \\
\hline \multirow{2}{*}{ II. dönem } & $\begin{array}{l}\text { Metodologija i tehnika izrade } \\
\text { naučnog rada }\end{array}$ & $\begin{array}{l}\text { Bilimsel Makale Hazırlamanın } \\
\text { Metodolojisi }\end{array}$ \\
\hline & $\begin{array}{l}\text { Osmanska paleografija } \\
\text { diplomatika }\end{array}$ & $\begin{array}{l}\text { Osmanlı } \\
\text { Diplomasi }\end{array}$ \\
\hline
\end{tabular}

Mostar, Hersek bölgesinin en büyük şehridir. Adriyatik’e açılan yol üzerinde bulunması nedeniyle Osmanlı döneminde de stratejik açıdan önemli bir yerleşim yeri olmuştur. Osmanlı döneminden kalma pek çok esere ev sahipliği yapan şehirde Müslüman Boşnak nüfus kadar Katolik Hırvat nüfus da bulunmaktadır. Farklı din ve kültürlerden insanların bir arada yaşamlarını sürdürdükleri Mostar'da tarihin yüklediği bir sorumluluk gereği Türkiye Cumhuriyeti'nin Başkonsolosluğu bulunmaktadır. Türk Dili ve Edebiyatı Bölümü’nün buradaki varlığı, Türkçenin Hersek bölgesindeki kalıcılığı açısından önemlidir.

\section{Uluslararası Saraybosna Üniversitesi}

Uluslararası Saraybosna Üniversitesi, Bosna ve çevresinde eğitim ve öğretim faaliyetlerini geliştirmek üzere Türk ve Boşnak girişimcilerin öncülüğünde 2001'de 
kurulan Saraybosna Eğitim Geliştirme Vakfi'nın (SEDEF) bir kuruluşudur. Bu vakıf üniversitesi 2004-2005 akademik yılında açılmıştır. Mühendislik ve Doğa Bilimleri, Ekonomi ve Yönetim Bilimleri, Sanat ve Sosyal Bilimler, Hukuk ve Eğitim Fakültelerine sahip olan üniversitenin eğitim dili İngilizcedir.

Uluslararası Saraybosna Üniversitesi'nde Türki Dili ve Edebiyatı Bölümü, 20202021 akademik yılında öğrenci kabulüne başlamıştır. Derslerin \%50'sinin Türkçe, kalan \%50'sinin ise İngilizce yürütüldüğü bölümde birinci sinıfa devam eden öğrenci sayısı 10'dur. Bölümde Türkiye'den görevlendirilmiş bir öğretim üyesi de görev yapmaktadır.

Tablo 6.

Uluslararası Saraybosna Üniversitesi Türk Dili ve Edebiyatı Bölümü Ders Kataloğu

\begin{tabular}{|c|c|}
\hline Lisans & Dersler \\
\hline \multirow{3}{*}{ 1. dönem } & Türk Dilbilgisi I (Ses Bilgisi) \\
\hline & Türkce Sözlü Illetisim Becerileri \\
\hline & Psikolojiye Giriş \\
\hline \multirow{4}{*}{ II. dönem } & Türk Dilbilgisi II (Sekil Bilgisi) \\
\hline & Edebiyat Bilgi ve Kuramları (Edebiyata Giriş) \\
\hline & Pedagojiye Giriş \\
\hline & Türkçe Dilbilgisi III (Sözcük Bilgisi) \\
\hline \multirow[t]{2}{*}{ III. dönem } & Yeni Türk Edebiyatı \\
\hline & Yaşam boyu Öğrenme \\
\hline \multirow{2}{*}{ IV. dönem } & Türkçe Dilbilgisi IV (Cümle Bilgisi) \\
\hline & Osmanlı Türkçesi \\
\hline \multirow{3}{*}{ V. dönem } & Dil ve Edebiyat Öğretme Öğrenme Yaklaşımları \\
\hline & Dilbilim \\
\hline & Halk Edebiyatı \\
\hline VI. dönem & $\begin{array}{c}\text { Dil Becerilerinin (Anlama-Anlatma) Öğretimi } \\
\text { Türk Dili Tarihi } \\
\text { Divan Edebiyatı } \\
\text { Didaktik }\end{array}$ \\
\hline VII. & Öğretme Teknikleri I \\
\hline dönem & Eğitim Psikolojisi \\
\hline VIII. & Öğretme Teknikleri II \\
\hline dönem & Türkçe Öğretimi ve Materyal Tasarımı \\
\hline IX. dönem & $\begin{array}{l}\text { Öğretme Teknikleri III } \\
\text { Türkçe Öğretiminde Değerlendirme }\end{array}$ \\
\hline X. dönem & $\begin{array}{c}\text { Bilimsel Araştırma Yöntemleri } \\
\text { Tez }\end{array}$ \\
\hline
\end{tabular}

Tablo 6'da sunulan dersler, programdaki zorunlu ve dili Türkçe olan derslerdir. Öğrenciler bir bu kadar daha, dili İngilizce olan dersleri üniversitenin genel ders havuzundan seçerek öğrenimlerini tamamlayacaklardır. Bosna Hersek’te hâlihazırda var olan dört Türkoloji bölümünün yanına bir beşincisinin açılması, Türkçenin geleceği adına olumlu bir gelişmedir. Bunda hiç şüphesiz Tercihim Türkçe Projesi önemli rol oynamaktadır. Öğrencilerin eğitimlerinin alt kademelerinde Türkçe dersini seçmiş olması, üniversitede de hepsinin olmasa da bir kısmının Türk Dili ve Edebiyatı bölümlerini tercih etmesini sağlamaktadır.

Tercihim Türkçe Projesi'nin amaçlarından biri de üniversitelerin Türkoloji bölümlerinden mezun olan öğretmenlerin bu projede görev almalarının 
sağlanmasıdır. Geçmişte Türkoloji bölümlerini hiçbir yere yerleşemeyen öğrenciler tercih ederken günümüzde bu projenin iş imkânı sunması, Almanca ve İngilizce bölümlerindeki öğretmenlerin daha çok rakibinin olması gibi nedenlerle Türkoloji bölümleri severek, istenerek tercih edilir hâle gelmiştir.

\section{Tartışma, Sonuç ve Öneriler}

Türkiye ile Bosna Hersek arasındaki ilişkilerin geliştirilmesinde siyasi, sosyal ve kültürel alanlarda karşılıklı pek çok adım atılmaktadır. Türkçe, bu ilişkilerin sağlamlaştırılmasındaki önemli aracılardandır. Balkanlarda Türkçenin yabancı dil olarak öğretiminin en yoğun yapıldığı ülke Bosna Hersek'tir. Yunus Emre Enstitüsüne ait üç Türk kültür merkezi, üniversiteler bünyesindeki beş Türkoloji bölümü ve Türkiye Cumhuriyeti'nin eğitim kurumu olan Maarif Okullarının varlığı bunun ispatıdır. Boşnakçanın da Türkiye'de öğretilebilmesi için Türkiye Cumhuriyeti adımlar atmaktadır. Bu doğrultuda, 2007'de hem Türkiye'de yaşamlarını sürdüren Boşnakların yararlanabilmesi hem de iki ülke arasındaki ilişkilerin akademik düzlemde de ele alınabilmesi için Trakya Üniversitesi bünyesinde Boşnak Dili ve Edebiyatı Bölümü hizmete açılmıştır. Bu karşılıklı adımlar iki ülke arasındaki bağları güçlendirmektedir.

Bosna Hersek'te yaşanan iç savaşın ardından ülkenin yönetim, sağlık, eğitim vb. gibi alanlarda tam olarak ideal bir yapıya kavuşamadığını söylemek mümkündür. Özellikle iş bulamama kaygısı nedeniyle ülke sürekli olarak Avrupa'nın çeşitli ülkelerine göç vermektedir. Bu ülkeler arasında Türkiye ilk sıralarda yer almaktadır. Öyle ki Türkçe öğrenme nedenleri arasında eğitimlerine Türkiye'de devam etmek ve Türkiye'nin sağladığı iş imkânlarından yararlanmak istemeleri ilk sıralarda yer almaktadır (Çangal, 2013).

Müslüman Boşnak, Katolik Hırvat ve Ortodoks Sırpların bir arada, barış içinde yaşama mücadelesi verdiği Bosna Hersek, hoşgörü ikliminin korunması gereken ülkelerin başında gelmektedir. Bu iklime katkı sunması bakımından Türk kültür merkezleri ve Türkoloji bölümlerinin ülkedeki varlığı ile ülkedeki ilk ve orta dereceli okullardaki Türkçe derslerinin devamlılığı, sadece Müslüman Boşnaklara değil Slav kökenli diğer halklara da Türk kültürünün tanıtımı noktasında önemli bir mesafe kat edildiğinin göstergesidir (Solak, 2011, s. 173).

Türkçenin Bosna Hersek’teki kalıcılığını sağlamak için Türkçe öğretimini yürüten kurum ve kuruluşlar desteklenmelidir. Üniversitelerin Türkoloji bölümlerine yeterli sayıda uzman akademisyenler görevlendirilmeli, bu akademisyenlerin öncülüğünde Bosna Hersekli Türkologlar yetiştirilerek üniversitelerin kadrolarına dâhil edilmeli ve bu sayede Türkoloji bölümlerinin hem nicel hem nitel açıdan gelişmesi sağlanmalıdır. Türkoloji bölümlerinin ders katalogları mutlaka güncellenmeli, Türkiye'deki Türk Dili ve Edebiyatı bölümlerinin ders katalogları ile benzerlik oranlarının artması sağlanmalıdır. Türkiye'deki üniversitelerin Türkoloji bölümleriyle Bosna Hersek’tekiler arasında iş birliği geliştirilmeli, öğrenci ve öğretim üyesi hareketliliği programları ile etkileşim arttırılmalıdır. Yunus Emre Enstitüsünün Tercihim Türkçe Projesi ülke genelinde genişletilerek sürdürülmeli, bu proje aracılığıyla ulaşılan okul ve öğrenci sayısının arttırılması için Türkiye Cumhuriyeti ilgili kurum ve kuruluşlarıyla seferber olmalıdır. Yürütülecek bu ve benzeri faaliyetler sayesinde Bosna Hersek'te Türkçe öğretimine ve Türk kültürüne olan ilginin artacağı düşünülmektedir. 


\section{Çıkar Çatışması ve Etik Bildirimi}

Bu makale kuramsal bir makaledir. Katılımcıların yer aldığı herhangi bir uygulama ve deney çalışması içermemektedir. Bu nedenle etik kurul onayı için başvuruda bulunulmamıştır. Makalede bilimsel, etik ve alıntı kurallarına uyulmuş; bilimsel gerçekler üzerinde herhangi bir çarpıtma yapılmamıştır. Etik ihlal sorumluluğunun yazara ait olduğu ve bu makalenin daha önce yayınlanmamış ve paylaşılmamış olduğu sorumlu yazar tarafindan taahhüt edilmiştir.

\section{Kaynakça}

Anadolu Ajansı. (2018). TIKKA'dan Bosna Hersek'te eğitime destek. https://www.aa.com.tr/tr/dunya/tikadan-bosna-hersekte-egitime-destek/1245298 adresinden 28 Kasım 2020 tarihinde alındı.

Anadolu Ajans1. (2019a). TIKKA Bosna'daki savaşta hasar gören okulu yeniledi. https://www.aa.com.tr/tr/dunya/tika-bosnadaki-savasta-hasar-goren-okuluyeniledi/1650147 adresinden 29 Kasım 2020 tarihinde alındı.

Anadolu Ajansı. (2019b). Saraybosna Yunus Emre Enstitüsünün 10. yll heyecanı. https://www.aa.com.tr/tr/dunya/saraybosna-yunus-emre-enstitusunun-10-yilheyecani/1614301 adresinden 12 Aralık 2020 tarihinde alındı.

Anadolu Ajansı. (2020). Bosna Hersek'teki mütevazi kütüphane Osmanlı döneminden kalma el yazmalarin y yllardir koruyor. https://www.aa.com.tr/tr/dunya/bosna-hersektekimutevazi-kutuphane-osmanli-doneminden-kalma-el-yazmalarini-yillardirkoruyor/2058795 adresinden 02 Aralık 2020 tarihinde alındı.

Balkan Günlüğü. (2020). TIKKA Bosna Hersek'te 24 ylla 900 proje siğdırdl. https://balkangunlugu.com.tr/2020/01/tika-bosna-hersekte-24-yila-900-proje-sigdirdi/ adresinden 28 Kasım 2020 tarihinde alındı.

Çangal, Ö. (17-19 Mayıs 2013). Bosna Hersekliler neden Türkçe ögreniyor? [Sempozyum Sunumu]. Uluslararası Türk Dili ve Edebiyatı Kongresi, Tiran, Arnavutluk.

Çangal, Ö., \& Göktaş, B. (6-8 Aralık 2019). Yabancı dil olarak Türkçe öğrenen temel seviyedeki Bosna Hersekli ögrencilerin yazma problemleri [Sempozyum Sunumu]. Uluslararası Türk Kültürü Sempozyumu Dil-Tarih-Coğrafya, Ankara, Türkiye..

Çelik, M. E. (2020). İki dillilik ve Bulgaristan Türklerinin iki dilliliği üzerine bir inceleme. Trakya Üniversitesi Edebiyat Fakültesi Dergisi, 10(20), 241-262. http://10.33207/trkede.684641

Geçer, G. O. (2009). Bosna-Hersek'te bir Osmanlı aydını: Salih Safvet Basiç. Tuzla Kantonu Arşivi.

Geçer, G. O. (16-18 Aralık 2010). Türkçenin çekilmeye direndiği bir vatan: Bosna-Hersek [Sempozyum Sunumu]. III. Uluslararası Dünya Dili Türkçe Sempozyumu, İzmir, Türkiye.

Ilgar, M., \& Çangal, Ö. (14-16 Kasım 2013). XV. yüzylldan günümüze Bosna Hersek’te Türkçenin durumu ve Türkçe öğretimi çalışmaları [Sempozyum Sunumu]. Uluslararası Dil ve Edebiyat Çalışmaları Konferansı "Balkanlarda Türkçe", Tiran, Arnavutluk.

İltar, L. (2020). Kültürlerarası iletişimsel dil yeterliği bağlamında göçmenlere Türkçe öğretimi. U. Başar \& B. Tüfekçioğlu (Ed.) Göçmelere Türkçe öğretimi (1. Baskı, s. 45-66) içinde. Nobel.

İbrahimović, F. (2012). Rjecnik Turcizama u Bosanskom jeziku s tumacenjem i prevodom na Engleski. JU Narodna i univerzitetska biblioteka "Dervis Susic", Tuzla Kantonu Arşivi. 
Karasar, N. (2012). Bilimsel araştırma yöntemi (24. Bask1). Nobel.

Kaya, F. (1997). Çă̆daş Boşnak edebiyatı antolojisi. Yapı Kredi.

Kayadibi, N. (2017). Makedonya'da Türkçe öğretmeni, Türk dili ve edebiyatı öğretmeni yetiştirme. Okuma Yazma Ĕ̆itimi Araştırmaları, 5(1), 15-25.

Kelağa Ahmet, İ. (9-10 Mayıs 2014). Lozan'ın 90. yılında Batı Trakya Türk azınlığının ĕgitim sorununa genel bir bakış [Sempozyum Sunumu]. Taraflarının Bakışıyla Lozan Uluslararası Sempozyumu, İstanbul, Türkiye.

Kırbaç, S. (2013). Türk dilinin Boşnakça ile ilişkileri ve Abdulah Škaljić. The Journal of Academic Social Science Studies, 6(4), 895-911.

Koltaş, N. (7-9 Mayıs 2014). Balkanlarda tasavvufun yayılışını hızlandıran etmenler: Reaksiyoner bir tavır olarak bogomilizm [Sempozyum Sunumu]. Osmanlı İlim, Düşünce ve Sanat Dünyasında Balkanlar, Edirne, Türkiye.

Köprülü, F. (1988). Osmanlı Devleti’nin kuruluşu. Türk Tarih Kurumu.

Özdemir, O. (2013). Kosova'da ilköğretim ikinci kademedeki Türk öğrencilerin yazılı anlatım becerileri. [Yayımlanmamış yüksek lisans tezi]. Gazi Üniversitesi.

Solak, E. (2011). Bosna- Hersek'te Türkçe ve Türk dili eğitimi ile ilgili çalışmalar. Çankırı Karatekin Üniversitesi SBE Dergisi, 2(2), 165-174.

TDBB. (2019a). Konya Büyükşshir Belediyesi'nden Bosna Srebrenik'e Türkçe sınıfi. http://www.tdbb.org.tr/?p=15028\&lang=tr adresinden 4 Aralık 2020 tarihinde alındı.

TDBB. (2019b). Bağcılar Belediyesi’nden Bosna Hersek Jablanica'ya Türkçe sınıfi. http://www.tdbb.org.tr/?p=15271\&lang=tr adresinden 6 Aralık 2020 tarihinde alınd.

TDV İslam Ansiklopedisi. (2005). Mostarlı Hasan Ziyâî (Müellif: Gürgendereli, M.). C. 30, İstanbul.

TIKA. (2016). TIKKA'dan Bosna Hersek'te Türkçe eğitime destek. https://www.tika.gov.tr/tr/haber/tika_dan_bosna_hersek_de_turkce_egitime_destek25093 adresinden 12 Aralık 2020 tarihinde alındı.

TİKA. (2017). TIKKA Bosna Hersek'te eğitim altyapılarına desteğini sürdürüyor. https://www.tika.gov.tr/tr/haber/tika_bosna_hersek_te_egitim_altyapilarina_destegini_sur duruyor-40550 adresinden 2 Aralık 2020 tarihinde alındı.

TİKA. (2020). Türk Iş̧birliği ve Koordinasyon Ajansı Başkanlı̆̆l. https://www.tika.gov.tr/tr/sayfa/hakkimizda-14649 adresinden 8 Aralık 2020 tarihinde alındi.

TMV. (2016). Türkiye Maarif Vakfi. https://turkiyemaarif.org/page/50-Turkiye-Maarif-Vakfi12 adresinden 13 Aralık 2020 tarihinde alındı.

TMV. (2020a). Dünyada Türkiye Maarif Vakfi. https://turkiyemaarif.org/page/42DUNYADA-MAARIF-16 adresinden 13 Aralık 2020 tarihinde alındı.

TMV.

(2020b).

Türkçe

ögretimi.

https://ba.maarifschools.org/country/1010/page/658/NASTAVA\%20TURSKOG\%20JEZI KA adresinden 13 Aralık 2020 tarihinde alındı.

YEE. (2009). Yunus Emre Enstitüsü. https://www.yee.org.tr/tr/kurumsal/yunus-emre-enstitusu adresinden 12 Aralık 2020 tarihinde alındı. 
YEE. (2018a). Bosna Hersek'in Teşanj şehrinde yeni Türkçe sinıfi açıldl. https://saraybosna.yee.org.tr/tr/haber/bosna-hersekin-tesanj-sehrinde-yeni-turkce-sinifiacildi adresinden 4 Aralık 2020 tarihinde alındı.

YEE. (2018b). Bosna Hersek Bužim'de Türkçe sinıfi açıldu! https://saraybosna.yee.org.tr/tr/haber/bosna-hersek-buzimde-turkce-sinifi-acildi adresinden 5 Aralık 2020 tarihinde alındı.

YEE. (2019). Mostar'da 2019 yllının ilk Türkçe kursu başladl. https://mostar.yee.org.tr/tr/haber/mostarda-2019-yilinin-ilk-turkce-kursu-basladi adresinden 29 Kasım 2020 tarihinde alındı.

Začinović, N. (2003). Bosna kütüphanelerindeki eski Türkçe gazetelerin dili. [Yayımlanmamış yüksek lisans tezi]. Ankara Üniversitesi.

\section{Extended Abstract}

Starting in early 21 st century, activities of teaching Turkish language have increased. The activities realized by Turkey to introduce Turkish language and culture across the world, students from various countries who demand to complete their higher education in Turkey, increasing interest in Turkish TV series, geopolitical location of Turkey for regular and irregular immigrants and existence of Syrians under temporary protection in Turkey can be discussed among the reasons of this situation. It has been noticed that there is a big demand in learning Turkish, especially, in Middle East, Caucasus, Balkans, geography of Turkistan, East Europe, most of Africa continent, Central and South America. To meet this demand, firstly Yunus Emre Institution and Turcology departments of various universities, centers of Turkish teaching, Maarif Schools and private courses have been carrying out their teaching activities both in Turkey and outside of Turkey.

Millions of cognates whose native tongue is Turkish have been living in Bulgaria, West Thrace, Macedonia and throughout Kosovo (Özdemir, 2013; Kelağa Ahmet, 2014; Kayadibi, 2017; Çelik 2020). Consequently especially in Balkans, on the one hand Turkish has been carrying out its existence as a native tongue, on the other hand, it is the most privileged language for the people demanding to learn in terms of historical, cultural, social and political relationship.

In this study, it has been purposed the followings; institutions carrying out teaching Turkish in Bosna Herzegovina today and their effectiveness, introducing and examining the Turcology departments in universities and discussing the medium- and long-term future of Turkish. It has been thought that this study will present a general perspective of the current status of Turkish in Bosnia Herzegovina and it will give detailed information to the experts who is to make a study. In this context, Turcology Departments of TIKKA, Yunus Emre Institution of Sarajevo, Yunus Emre Institution of Mostar, Yunus Emre Institution of Fojnica, Maarif Schools of Sarejevo, Zenica, Tuzla, Mostar Džemal Bijedić and International University of Sarajevo have been examined. In this study, this study has been carried out with raster pattern out of quantitative study methods. "Raster patterns are research approaches purposing to describe a situation in the past or still exists as it is. Phenomenon, individual or an object discussed is tried to be described in its own conditions. There is no effort to change, effect in any ways" (Karasar, 2012, s.77). Study group is consisted of institutions carrying out teaching of Turkish in Bosnia 
Herzegovina and institutions supporting them. The major studies of TIKA oriented teaching of Turkish in Bosnia Herzegovina is to provide opening of Turcology departments in Tuzla in 2001 and Zenica in 2005, to supply reconditioning and hardware support to school in various cities in which Turkish is taught as an optional subject, to their develop technological substructure and superstructure possibilities.

Among the centers in Bosnia Herzegovina, the one in Sarajevo has the potential to accept most students. In this center, there are 3 course term beginnings in a year. At least 8 students must apply to be able to open any course. The center in Sarajevo opens courses in all levels and has over 250 students.

In Yunus Emre Institution centers, not only Turkish instruction is provided, but also courses for introducing and teaching traditional Turkish handicrafts are organized. Among them; islamic calligraphy, tile embroidery, marbling art, wood printing come to the fore. Ottoman Turkish, Turkish food and ney courses are also offered at the centers. As of 2020, traditional Turkish archery course has also started in the center. In addition to all these courses, a Turkish Conversation Club is opened in the center and attracts great attention from Bosnia and Herzegovina.

To provide permanence of Turkish in Bosnia Herzegovina, institutions carrying out teaching of Turkish should be supported. Sufficient number of expert academists should be assigned to Turcology departments of universities, in leadership of these academists, Turcologs from Bosnia Herzegovina should be raised and they should be placed in staff of the universities thus, Turcology departments should be developed in terms of both quantitative and qualitative.

Turkish elective courses of Yunus Emre Institution should be maintained by expanding across the country, to increase the number of schools and students reached by this project, related institutions of Republic of Turkey should take action. The relationship between Turcology departments of the universities in Turkey and the ones in Bosnia Herzegovina should be improved, Interaction should be increased by the programs of students and teaching staff mobilities. By means of carrying out this and similar activities, it has been thought that the interest in teaching of Turkish and Turkish culture in Bosnia Herzegovina will increase. 